\title{
Intertextuality of Pupuh pangkur in Serat Wulangreh and the Implications for the Javanese Character Education
}

\author{
Veronika Unun Pratiwi \\ Veteran Bangun Nusantara University (UNIVET), Sukoharjo, Central Java, Indonesia \\ pratiwiunun@yahoo.co.id
}

\begin{abstract}
This study seeks to examine Javanese traditional ethics and teachings, especially through an intertextual reading of Javanese Pupuh Pangkur chant text in Serat Wulang Reh. This study sought to learn more about the positive values that shape Javanese noble morals, as well as their representation and implementation in modern Javanese society, and their relationship to the idea of maintaining arts and culture in accordance with Javanese philosophy. The script writer Pupuh Pangkur wishes to remind the audience to be humble rather than arrogant. A person who exaggerates his strength or brags about his good deeds is considered arrogant, and such behavior is prohibited. An arrogant person also enjoys pointing out the flaws and shortcomings of others in public. People who exhibit these characteristics are despicable and should be avoided. People with bad personalities frequently commit acts such as taking away other people's rights, stealing, cheating, or corruption. Their primary goal in life is to make money and accumulate wealth. These people are influenced by worldly desires to pursue personal pleasures such as wasting money, drinking, having affairs with women, and so on.
\end{abstract}

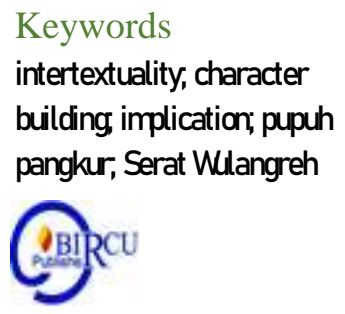

Keywords

intertextuality, character

building, implication; pupuh

pangkur, Serat Wulangreh

\section{Introduction}

The dynamics of manuscript study are frequently confronted by two major issues. First, there is ambiguity between texts that are boring because they are difficult to understand and the recognition of the valuable values contained in them. Second, there is the possibility of text research duplication, particularly in terms of objects and methods, whether intentional or unintentional (Ekadjati, 2000: viii-ix). The first issue can be resolved by emphasizing the researcher's determination and efforts in selecting and reviewing the manuscripts. In fact, if necessary, researchers can enlist the help of experts in their fields to help them read and understand the text because it is not only written in the original language but also in an ancient form of language that is rarely transformed over time (Baried, 1994: 16-17). To avoid duplication or plagiarism, researchers must conduct comprehensive literature studies with some limitations for the second issue. This is made possible by easy access to library resources and online tools that help in the process. Because of the essential values that must be extracted from existing manuscripts, the numerous difficulties in researching them should not dampen researchers' enthusiasm.

Human life experiences affect human knowledge in viewing cultures and interacting with different environments. The process of seeing or paying attention to this is then called the introduction of social studies. One is more concerned that the experience experienced by every condition prevents him from thinking conventionally (Gray in Srinarwati, 2018)

The Javanese people's socio-cultural behavior always refers to traditional Javanese customs that are rooted in palace values. The palace is thought to be the center of the 
cosmos, which has a strong influence on living a peaceful and harmonious life. This concept manifests itself in ideas, behavior, and various forms found in our environment. The Pupuh Pangkur manuscript was originally introduced in the Keraton. The manuscript is the creation of Keraton poets such as Yosodipuro and RNg. Ronggowarsito, as well as kings such as Paku Buwana IV (from the Kasunanan Palace) and Mangkunagara IV (from the Mangkunegaran Palace). The Pupuh Pangkur manuscript was originally created as a narrative speech that was delivered to the children / ancestors (sentana dalem) and abdi dalem (someone from outside the palace or those who are devoted to the palace). Furthermore, Pupuh was distributed to the public (kawula dalem). Despite the fact that the Pupuh Pangkur script is sung in a melodious manner, it is critical for listeners to understand the content / meaning of Pupuh. However, few people understand what message Pupuh Pangkur conveyed and how it affects their lives in general.

Considering that Pupuh Pangkur is written in Javanese, its meaning and message have become part of the Javanese community's life guidelines. A number of studies have been conducted to investigate Pupuh Pangkur and Serat Wulangreh (Wreksosoehardjo, 2009; Simuh, 1988; Ardani, 1995; Siswokartono 2003; Muslich, 2005; and Anjar Any, 2001), one of which discusses story books with pictures based on pupuh pangkur in Serat Wulangreh for learning Javanese (Ardiyana, 2020). Their study focused on the cosmological analysis of Javanese poetry songs and their translation into Indonesian (Sanjaya, 2017), as well as on the style of poetry songs (Budilaksono, 2018). In addition, the analysis is quite general, unrelated to a broader cultural context such as Javanese morals in the applied case (Santosa, 2016), and intertextuality studies of the New Asmaradana, Indonesian Contemporary Poetry (Suyitno, 2017). More specifically, the impact of noble teachings as reflected in the intertextual analysis of pupuh pangkur in Serat Wulangreh from the Javanese moral values philosophy and the perspective of local ethics in fostering noble morals of millennial youth needs to be studied more deeply.

According to Gadamer, "a literary work does not appear to the world as a finished and neatly wrapped bundle of meaning." The meaning is determined by the interpreter's historical situation (Selden, 1993: 117). For Karl Mannheim, the interpreter or writer is in Kulturgebundenheit (cultural attachment) and Zeitgeist (the spirit of the times) (Lubis, 2000: 10). Meanwhile, Iser suggests that the text is not a perfect presentation but consists of empty parts. The reader fills in the blanks that contain ambiguous meanings in the text, he fills them freely according to his experience. From the reader's point of view, the meaning of a literary work is essentially unstable (Eagleton, 1985: 76-81)." Derrida, a philosophical school follower, denies the stability of meaning. Because meaning is always in the process, there is no standard and permanent meaning (Sim, 1999: V). The intertextuality approach is one literary approach based on Reader Theory.

The intertextuality approach is one of the approaches in uncovering the meaning of a literary work. "Intertextuality is an approach to obtain the full meaning of a literary work in relation to other works that become its hypogram (previous texts), both in the form of fictional texts and poetry" (Nugiyantoro, 1998: 54; Suyitno, 2017). Intertextuality studies are based on the assumption that a work cannot possibly be born from a cultural vacuum whenever it is written. In the form of previously written texts, cultural elements, including all social norms and traditions (Nugiyantoro, 1998: 50). Kristeva argues that the text is related as follows: every text take shape as a mosaic of citations, every text is the absorption and transformation of other text. "Every text takes the form of a mosaic of excerpts, and each text absorbs and transforms other texts" (Culler, 1975: 139). Kristeva's thought contributes to the emergence of intertextuality thinking, namely that language can be reduced to dimensions that consciousness can accept. Consciousness is not a static 
subject, but exists in a fictitious form (Lechte, 1994; 2001: 221). According to Foucoult (1971; 2003: 30), there is no society that does not have major narratives which are then repeated and varied, formulas of ordinary texts, ritual texts that are spoken in certain circumstances; things that have been said are then discussed again because people suspect that there is something secret and "splendor" hidden in what is said. This fact raises the issue of understanding literary works.

\section{Research Methods}

This study is based on Iser's (1982: 54-55) perspective that "literature has two sides, namely artistic and aesthetic, artistic is owned by the text created by the author, and aesthetics is owned by the reality that is perfected by the reader." The problems expressed are centered on the theme, and from this theme, the meanings surrounding the theme are revealed, and how this theme is polished with educational concepts such as Gadamer's statement that a literary work does not appear to the world as a finished and neatly wrapped bundle of meaning, but the meaning depends on the interpreter's historical situation.

The study of intertextuality is based on how the author reconstructs Pupuh Pangkur into Serat Wulang Reh, which manifests moral values or character that are scattered throughout the 13 existing pupuh chants. The study of intertextuality traces the hypogram of the text of Javanese thought or moral concepts, as well as the social conditions at the time when the text was created, which are thought to have influenced the author, either directly or indirectly, in the reconstruction of Pupuh Pangkur.

\section{Results and Discussion}

\subsection{Intertextuality in Pupuh Pangkur Serat Wulangreh by Paku Buwana IV}

Serat Wulangreh is very popular among Javanese people. According to Poerbatjaraka (Purwadi et al. 2005), Serat Wulangreh is very important in the daily lives of Javanese people. Serat Wulangreh's message, on the other hand, is less well-received among the younger generation. According to the findings of a study conducted in Javanese society, the youth are unaware of Pupuh pangkur (both in Serat Wedhatama and Serat Wulangreh). Court poets' advice is always conveyed in the form of Pupuh. Through the stanzas, the person who listens to the advice does not feel compelled to obey it, but happily pays attention to the melody. The Javanese have a very strong tradition to uphold; For example, they have to be well behaved everywhere, all the time. It is a general rule that a young person must respect his elders (Harsono, 2005).

Pakubuwana IV reminded younger generations, as part of his advice, that life has two opposing qualities: good and bad. Everyone should be taught to have good character. If a person has a good character, good things happen to him. Furthermore, it is believed that by doing good, a person will be rewarded by God. Making mistakes, on the other hand, will have a negative effect on someone. Therefore, Pakubuwana IV continues to advise and remind the public of the importance of distinguishing between good and bad deeds. People who understand the concepts of good and evil are less likely to engage in negative behavior. Conforming to religious teachings, for example, through worship, worshiping God or prayer, building good relationships with others, and so on, are examples of good deeds that a person can perform. Harming others, stealing, gambling, cheating, killing, and disturbing others' peace are all examples of bad attitude. 


\section{Pupuh Pangkur}

09

Alaning liyan den andhar, ing becike liyan dipunsimpeni, becike dhewe ginunggung, kinarya pasamuan, nora ngrasa alane dhewe ngendhukur, wong mangkono wateknya, nora kena denpedhaki.

The ugliness of others is disperse, while the goodness of (others) is hidden; the goodness itself is lauded and mentioned in meetings; it does not feel like its own ugliness accumulates. A person with such a personality is not worthy of your attention.

10

Iku wong durjana murka, nora nana mareme jroning ati, sabarang karepanipun, nadyan wusa katekan, karepane nora mari saya banjur, luwamah lawan amarah, iku kang den tut wuri.

Such a person is referred to as a greedy criminal because he never feels satisfied even after all of his desires have been satisfied; his will never stops, but instead grows stronger over time, indulging the lust of lawama and anger.

11

Ing sabarang tingkah polah, ing pangucap tanapi lamun linggih, sungkan asor ambekipun, pan lumuh kaungkulan, ing sujanma pangrasane dhewekipun, nora nana kang memadha, angrasa luhur pribadi.

In all of his attitude, whether speaking or sitting, his character does not want to be defeated by others, does not want anyone to equal him, and he considers himself to be the highest.

If a person acts without prior thought or consideration, the results will be less than ideal. An action without a concept will cause others to misinterpret the meaning of the action. People will find the action inappropriate if it is performed in front of a large crowd. These actions should be avoided, especially when socializing with the community, because they do not reflect the character of society as a whole. Action taken on the heat of the moment is unlikely to produce positive outcomes and benefits for the perpetrator or others. As a result, the person carrying out the action is advised to do some introspection. They must understand that their actions are inappropriate and ineffective, and they should be reminded to plan their future actions more carefully.

Human life in the world is divided into two categories: intelligent and unintelligent, high and low class, day and night, rich and poor, good and bad. Every distinction has ramifications. Smart people solve problems easily, whereas unintelligent people struggle with problems and are more likely to be cheated by others. Others hold high regard for the upper-class society, in contrast to the lower-class society, which is uncared for. Rich people will easily dominate the poor or have more experience, allowing them to do a lot of charity because of their wealth. Reality demonstrates that every person is born into a world full of sins and errors. As a result, anyone who has wronged someone else must immediately apologize. Someone who disobeys God, on the other hand, must repent and seek forgiveness from Him.

The preceding explanation is meaningless before God because the highest honor before Him is a person who believes and has faith. Human faith and devotion to God are demonstrated when a person is concerned with non-secular matters rather than focusing solely on worldly affairs. As a result, good people are judged by their actions in daily life. For example, when they walk, their eyes are fixed forward on the path they are taking; when they sit, they place both feet on the floor rather than crossing their legs; and when 
they talk to other people, their tone is always humble, and they always look directly into the eyes of the person they are bringing with them. Moreover, when speaking, good people give listeners the opportunity to provide feedback, and when other people are talking, they pay attention and do not interrupt.

It should be emphasized further that adolescents must behave well when communicating with others. If they need to ask someone a question, such as asking for directions, they need to get closer and closer to the listener. If they are driving or driving, they must get off the vehicle before speaking. Before asking for direction, they should first greet the listener and then thank the listener for taking the time to provide the direction. In addition, it is important to avoid the following behaviors: (1) Bad behavior that is spoken, for example talking about useless things, making fun of others, mentioning other people's bad names, prejudice, criticizing and finding fault with others, lying, doing useless things, accusing others with cruelty, hypocrisy, and showing off / arrogant. (2) Bad deeds, such as delinquency, cowardice, hatred, luxury, injustice, delinquency, arrogance, fleshly and treachery.

The above rules apply to all individuals regardless of gender, age, and educational and religious background; because in the community, everyone is equal. A religious leader who should have more religious knowledge than ordinary people must become a role model in society. An adult man, as a husband, must protect his family and be the leader of his wife and children. Likewise, the wife has responsibilities to her husband and the duty of taking care of the family, taking care of household budgets, and taking care of the house and children.

Another quote that describes a person's personality is "sabda brahmana raja sepisan dadi tan kena wola-wali," which means, "the king's words are sure and must be consistent". The phrase suggests that theologians and leaders should make statements only after careful consideration, because their commands and instructions must be consistent and respected by society (Purwadi, et al. 2005). This is true not only for kings or religious leaders, but also for ordinary people. Everyone should always think before speaking to avoid hurting the feelings of others. Every statement made must be true and accountable. It is critical, for example, to think positively about others and to avoid all forms of prejudice.

13

Aja lunyu lemer genjah, angrong pasanakan nyumur gumuling, ambubut arit puniku, watek datan raharja, pan wong lunyu nora pantes dipunenut, monyar-manyir tan anteban, dela lemeran puniku.

Do not behave lunyu lemer, pasanakan nyumur gumuling, dan ambubut arit because such qualities will not save you, you should not embrace them. Lunyu character means that the words cannot be held, while the nature of lemer

14

Para penginan tegesnya, genjah iku cak-cekan barang kardi, angrong pasanak liripun, remen ulah miruda, mring rabine sadulur miwah ing batur, mring sanak myang prasanakan, sok senenga den ramuhi.

It is easy to be tempted by something. genjah means happy to say dirty, angrong pasanakan means happy to have an affair with someone's wife, and if you already love the wife of a friend or relative, it must be done 
It was prophesied that there would be moral decline in this world. One of the signs is that recently, negative behavior such as jealousy, greed, dishonesty, laziness, jealousy, judgmental, arrogant, cunning, ignorant, skeptical, and scandal are more frequently encountered than positive behavior. Competition between political opponents as well as unfair competition for seats in parliament is very common. Negative competition is characterized by a desire to focus only on winning, being the best, and beating your opponent. This may be one of the causes of rampant corruption in Indonesia which is still very difficult to eradicate.

Some of the causes of this moral decline are moral decadence, decreased religious observance, widespread accusations against religion, excessive fanaticism, and grossly underestimating or underestimating religious teachings (Mahmud, 2004). Moral decadence refers to a state in which a person completely neglects the importance of religion in everyday life. This condition is believed to be the influence of the western world. In the point of view of western culture, religious or spiritual beliefs are irrelevant to life. Western culture is open to adultery, homosexuality, alcoholism, and the like. When religious observance begins to decline, people's faith and willingness to sacrifice for the sake of their religion will fade. Accusations against religion are rife everywhere. The accusation aims to eliminate people's belief in God and religion. Excessive fanaticism towards certain objects such as community leaders, religious leaders, certain groups or organizations related to politics, economy, culture and sports; political parties, ethnicity, race, language, customs and culture also cause moral decline. The attitude of overvaluing or underestimating religious teachings indicates a shallow thought and understanding of the religious community. When moral values are belittled, people's responsibility to God and others will begin to decrease, people will start to make many mistakes and bad decisions, and they will be controlled by lust. This characterizes man's moral decline.

To prevent someone from inheriting negative traits, several traits that must be studied include: (a) Consistent, meaning that a person must be obedient and determined in carrying out religious orders according to God's guidelines / rules. (b) Develop religious loyalty by obeying all religious orders and avoiding all prohibitions. (c) Willingly devoting all abilities to obtain God's blessings and taking all problems seriously rather than trivializing problems. (d) Be tolerant and help others in need. (e) Developing a moderate attitude by being able to equate the physical with spiritual interests, and worldly with spiritual matters.

\subsection{Intertextuality in Understanding Pupuh Pangkur and Its Relation to the Current Social Context}

There are two definitions of Serat Wulangreh, the first version claims that the name comes from the word "reh" (ngereh) which means command or instruction. The second version believes that the word "Reh" means everything related to human life. Serat Wulangreh Pupuh Macapat yang meliputi Dhandanggula, Kinanthi, Gambuh, Pangkur, Maskumambang, Megatruh, Durma, Pocung, Mijil, Asmaradana, Sinom, and two other additional pupuhs, Wirangrong and Girisa. From all the Pupuh in Serat Wulangreh, contains teachings about the port or service to the nation or society. This Pupuh, for example, states that positive activities associated with local customs, such as mutual cooperation, should be encouraged, carried out, preserved, and developed. Furthermore, this stanza states that individuals must be able to distinguish between positive and negative behavior in order to avoid harming others. A person is believed to be able to distinguish between good and bad when that person obediently observes religious orders. In Indonesia, the mass media often promote negative behavior that exposes viewers to negative influences. Lots of news about corruption, murder, robbery, robbery, fraud, rape and other 
types of crimes are found in the media. Practicing the values taught through Pupuh Pangkur in Serat Wulangreh is an effort to prevent the negative influence of the media on Javanese society. It is important that people not only enjoy the beauty of Pupuh, but also apply the values of goodness in their daily lives. The application of these values can be done, for example, by practicing good manners and manners wherever and whenever.

\section{Conclusion}

The Pupuh Pangkur chant in Javanese, especially in Serat Wulangreh, is a means of communication used by Pakubuwana IV to convey messages to his relatives in the palace and to the community in general. However, the meaning and message reflected in the stanza is not easy to understand because it is written in Javanese. Some people believe that staple has a deep meaning about when a person enters the final stage of the process of death, whereas many people are afraid of death. Therefore, not many people are interested in studying Pupuh. Considering this, it is important for the younger generation to begin to learn and understand the meaning of Pupuh, especially to be ready to face the end of their lives, while preserving Javanese culture and traditions. The script writer Pupuh Pangkur wants to remind the public to be humble, not arrogant. A person who exaggerates his strength or shows off his good deeds is considered arrogant; and this behavior is prohibited. Arrogant people also like to point out the shortcomings and shortcomings of others in public. People with these characteristics are despicable and should be avoided. People with bad personalities usually commit acts such as taking away other people's rights, stealing, cheating, or corruption. Their main purpose in life is to raise money and build wealth. These people are controlled by worldly desires to pursue personal pleasures such as wasting money, drinking, having affairs with other women, etc.

\section{References}

Any, Anjar. (2001). Menyingkap Sêrat Wédotomo.Semarang: Aneka Ilmu.

Ardani, M. (1995). Al Qur'an and Sufisme Mangkunagara IV (Studi Serat-Serat Piwulang). Yogyakarta: Anda Bhakti Wakaf.

Ardiyana, V. (2020). Pengembangan Buku Cerita Bergambar Berbasis Serat Wulangreh Pupuh pangkuruntuk Pembelajaran Bahasa Jawa SMP di Kota Semarang. Piwulang: Jurnal Pendidikan Bahasa Jawa, 7, (2), 28-33. https://doi.org/10.15294/piwulang.v7i2.29601

Bahreisj, Hussein. (No Year). Hadits Shahih Al-Jamus Shahih Bukhari-Muslim. Surabaya: CV Karya Utama.

Baried, Siti Baroroh, et al. (1994). Pengantar Teori Filologi. Yogyakarta: Badan Penelitian dan Publikasi Fakultas (BPPF) Seksi Filologi Fakultas Sastra Universitas Gadjah Mada.

Budilaksono, Satrio Bagus, (2018), "Serat Wulangreh: Kajian Antropologi Sastra dan Nilai Karakter Serta Relevansinya Sebagai Materi Ajar di Sekolah Menengah Pertama", [Academic Thesis], Fakultas Keguruan Dan Ilmu Pendidikan Universitas Sebelas Maret Surakarta, https://eprints.uns.ac.id/41988/1/K4213066_pendahuluan.pdf

Chulakaratan, Siriruj, (March 2016), ASEAN Economic Community (AEC)'s Opportunities for Trade and Investment for MSMEs (Micro, Small and Medium Enterprises), retrieved from: www.cpg-online.de/2016/05/01/opinion-pool-the-aseaneconomic-community-aec/ 
Culler, Jonathan. (1975). Strukturalism and Linguistic Models (Part One). Great Britain: Unwin Brothers Limited. The Gresham Press, Old Woking, Surrey, England.

Eagleton, Terry. (1983). Literary Theory. An Introduction, Oxford - England: Basil Blackwell Publisher Limited.

Ekadjati, Edi S., et al. (1999). Direktori Naskah Nusantara: Antologi Sastra Daerah Indonesia. First Edition. Jakarta: Yayasan Obor Indonesia

Harsono, Andi. (2005). Tafsir Ajaran Serat Wulangreh.Yogyakarta: Pura Pustaka.

Indonesia Economic Update (2019), "Making Indonesia 4.0: Indonesia's Strategy to Enter the 4th Generation of Industry Revolution, retrieved from: "https://www.investindonesia.go.id/en/why-invest/indonesia-economicupdate/making-indonesia-4.0-indonesias-strategy-to-enter-the-4th-generation-of-ind

Khalif, Khalit Abdul Mu'thi. (2005). Nasihat untuk Orang-orang Lalai.Translated by Abdul Hayyie al- Kattani and Arif Chasanul-Muna. Jakarta: Gema Insani.

Lubis, Nabilah. (1996). Naskah, Teks dan Metode Penelitian Filologi, Jakarta: Forum Kajian \& Sastra Arab Fakultas Adab Syarif Hidayatullah. 1995 Syekh Yusuf Al-Taj Al-Makasari Menyingkap Intisari Segala Rahasia. Fakultas sastra Universitas Indonesia dan École FranÇaise d'Extrème-Orient. Bandung: Mizan.

Namawi, Imam. (1999). Hadist Riyadhus Shalihin.Translated by Achmad Sunarto.Jakarta: Pustaka Amani.

Nurgiyantoro, Burhan. (1998). Teori Pengkajian Fiksi. Yogyakarta: Gadjah Mada University Press

Purwadi, et al. (2005). Ensiklopedi Kebudayaan Jawa.Yogyakarta: Bina Media.

Sanjaya, Yandi Benny, (2017), "Serat Wulangreh Yasa Dalem Sri Susuhunan Pakubuwana IV", available online: https://docplayer.info/72968739-Serat-wulangreh-yasa-dalemsri-susuhunan-pakubuwana-iv.html

Santosa, S. (2016). Nilai-Nilai Pendidikan Moral Dalam Tembang Macapat Sebagai Penguatan Pendidikan Karakter dalam Kurikulum 2013. [Telaah Budaya Lokal]. AlBidayah: Jurnal Pendidikan Dasar Islam, 8, (1), June 2016

Selden, Raman. (1993). Panduan Pembaca Teori Sastra Masa Kini. Diterjemahkan oleh Rachmat Djoko Pradopo. Yogyakarta: Gadjah Mada University Press.

Simuh, (2002), Sufisme Jawa Transformasi Tasawuf Islam ke Mistik Jawa, Yogyakarta: Bentang Budaya.

Soetomo Siswokartono, W.E. (2006.) Sri Mangkunagara IV Sebagai Penguasa and Pujangga (1853-1881). Semarang: CV Aneka Ilmu.

Suyitno, (2017). New Asmaradana in Indonesian Contemporary Poetry and Malayan Pop Song: Product of Rooted Culture or New Interpretations?, The Southeast Asian Journal of English Language Studies, 23, (1) (2017): 86-97

Spradley, James P. (1997). Metode Etnografi (Translated by Misbah Zulfa Elizabeth) Yogyakarta: PT Tiara Wacana.

Sunaryo, Wreksosuhardjo, (2009). Sesuluh Dwi Basa. Surakarta: UNS Press

Susanto, H. (September 11, 2010). "Serat Wulangreh", retrieved from: https://bagawanabiyasa.wordpress.com/2010/09/11/serat-wulangreh/

Srinarwati, D. (2018). The Disclosure of Life Experience And Its Expression in Cultural Studies Perspective. Budapest International Research and Critics Institute-Journal (BIRCI-Journal). P. 125-141

Thomas, Brook (1982). Readomg Wolfgang Iser or Responding to a Theory of Response. Comparative Literature Studies, 9, (1) (Spring, 1982), pp. 54-66, https://www.jstor.org/stable/40246294 